$\begin{array}{ll}\text { Abstracta Iranica } & \begin{array}{l}\text { Abstracta Iranica } \\ \text { Revue bibliographique pour le domaine irano-aryen }\end{array} \\ & \text { Volume } \mathbf{3 4 - 3 5 - 3 6} \text { | } 2017 \\ \text { Comptes rendus des publications de 201 1-2013 }\end{array}$

\title{
Pierfrancesco Callieri. Some remarks on the Use of Dressed Stone Masonry in the Architecture of Sasanian Iran
}

\section{Rémy Boucharlat}

\section{(2) OpenEdition \\ Journals}

Édition électronique

URL : http://journals.openedition.org/abstractairanica/41806

DOI : 10.4000/abstractairanica.41806

ISSN : 1961-960X

Éditeur :

CNRS (UMR 7528 Mondes iraniens et indiens), Éditions de l'IFRI

Référence électronique

Rémy Boucharlat, « Pierfrancesco Callieri. Some remarks on the Use of Dressed Stone Masonry in the Architecture of Sasanian Iran », Abstracta Iranica [En ligne], Volume 34-35-36 | 2017, document 20, mis en ligne le 30 décembre 2016, consulté le 02 octobre 2020. URL : http://journals.openedition.org/ abstractairanica/41806 ; DOI : https://doi.org/10.4000/abstractairanica.41806

Ce document a été généré automatiquement le 2 octobre 2020.

Tous droits réservés 


\title{
Pierfrancesco Callieri. Some remarks on the Use of Dressed Stone Masonry in the Architecture of Sasanian Iran
}

\author{
Rémy Boucharlat
}

\section{RÉFÉRENCE}

Pierfrancesco Callieri. « Some remarks on the Use of Dressed Stone Masonry in the Architecture of Sasanian Iran ", in : H. Fahimi and K. Alizadeh, eds., Nāmvarnāmeh, Papers in Honour of Massoud Azarnoush. Tehran, Iran Negar, 2012, p. 153-162.

1 Utile revue des constructions sassanides en pierres taillées et appareillées. Selon l'A., ce type de maçonnerie de prestige serait limité aux palais et aux monuments religieux dynastiques, de Fīrūzābād (TaḦ-e Nešīn) et Bī̌āpūr (« temple » et Palais B) TaH̆t-e Soleymān, partie inférieure des murs du complexe Ouest), puis Kangāvar, en passant par Tāq-e Gerrā. Cette architecture se veut une imitation de celle de Persépolis, d'origine ionienne, œuvre des " ancêtres " des rois sassanides, et toujours visible sur place. Cela n'exclut pas un nouvel apport occidental, cette fois, des techniques du monde romain syrien.

\section{AUTEURS}

RÉMY BOUCHARLAT

CNRS, Lyon 